\title{
Realization and Characterization of ZnO/n-Si Solar Cells by Spray Pyrolysis
}

\author{
H. H. Afify ${ }^{1}$, S. H. EL-Hefnawi', A. Y. Eliwa ${ }^{2}$, \\ M. M.Abdel-Naby ${ }^{3}$ and N. M. Ahmed ${ }^{2}$ \\ ${ }^{1}$ Physics Department, National Research Center, Dokki, Cairo, Egypt. \\ ${ }^{2}$ Electronics Research Institute, National Research Center Building, Dokki, \\ Cairo, Egypt \\ ${ }^{3}$ Electronic and Communication Department, Tanta University, Tanta, Egypt
}

Indium doped zinc oxide ( $\mathrm{ZnO}$ : In) thin films have been prepared using spray pyrolysis technique. The used spray solution has a molarity of $0.2 \mathrm{M}$ of chemical pure hydrated zinc acetate $\left(\mathrm{Zn}\left(\mathrm{CH}_{3} \mathrm{CO}_{2}\right) 2 \mathrm{H}_{2} \mathrm{O}\right)$ and $2 \%$ by weight of indium chloride $\left(\mathrm{InCl}_{3}\right)$. Zinc acetate was dissolved in a mixture of bidistilled water and methyl alcohol $\left(80 \% \mathrm{H}_{2} \mathrm{O}: 20 \% \mathrm{CH}_{3} \mathrm{OH}\right)$. The $\mathrm{ZnO} / \mathrm{n}$-Si solar cells have been realized by depositing the ZnO: In on Si wafers separated by a thin interfacial $\mathrm{SiO}_{2}$ layer ameliorating the barrier height. The realized $\mathrm{ZnO} / n$-Si solar cells shows rapid degradation of the cell performance with storage time in dark. This could be attributed to the porosity of $\mathrm{ZnO}$ films which allows the oxygen to diffuse through it increasing the thickness of the interfacial $\mathrm{SiO}_{2}$ layer due to the reaction with Si. The degraded characteristics of $\mathrm{ZnO} / \mathrm{n}$-Si junction solar cells can be minimized by depositing a conducting layer of indium tin oxide (ITO) as a barrier layer on $\mathrm{ZnO} / \mathrm{n}$-Si. A thin layer of ITO is deposited on ZnO films to suppress the oxygen diffusion to Si wafer. The best output parameters obtained for ITO/ZnO-nSi cells are; open circuit voltage $V_{O C}=0.44 \mathrm{~V}$, short circuit current density $J_{S C}=20 \mathrm{~mA} / \mathrm{cm}^{2}$, fill factor $F F=0.6$ and efficiency $\eta=5.28 \%$.

\section{Introduction:}

Transparent Conducting Oxides (TCO) has been widely studied and received considerable attention in recent years. The band gaps of these materials are large enough to be transparent to most of the useful solar spectrum and the resistivity is small enough to avoid series resistance effect. Indium doped zinc oxide ( $\mathrm{ZnO}: \mathrm{In}$ ) has emerged as one of the most promising window materials due to its large band gap $(3.2 \mathrm{eV})$, high transparency and low resistivity managed by doping and heat treatment. $\mathrm{ZnO}$ thin films have been prepared by wide variety of techniques such as sputtering [1], evaporation 
[2], chemical vapour deposition (CVD) [3], sole-gel [4] and spray pyrolysis [5]. Spray pyrolysis deposition is particularly attractive since it is relatively fast, vacuumless, simple and more economics. The electro-optical properties are generally dependent on the deposition and post deposition conditions, because these properties changed significantly with the absorption and desorption of oxygen that occurs during these process.

\section{Experiment:}

Phosphorus doped two-inch diameter monocrystalline n-Si wafers with thickness of 280-300 $\mu \mathrm{m}$ and resistivity of 10-20 $\Omega \mathrm{cm}$, oriented in (100) plane were used. They were cut into relatively small segments $(1 \mathrm{~cm} \times 1 \mathrm{~cm})$ to be used as base semiconductor for semiconductor-insulator-semiconductor (SIS) solar cells. The process steps of the $\mathrm{ZnO} / \mathrm{n}$-Si solar cells are shown in Fig. (1).

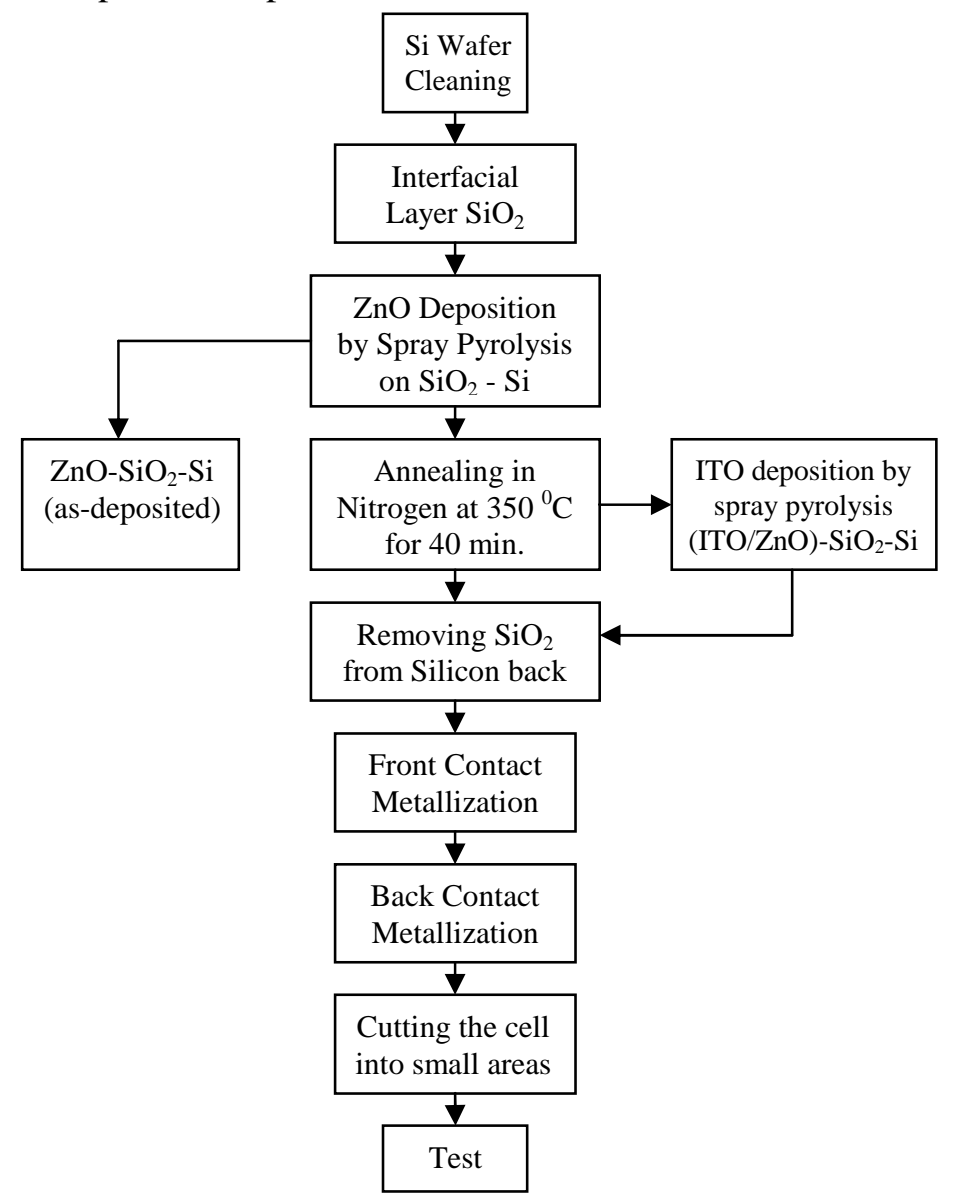

Fig. (1): The general Processing for the three solar cell configurations (as -deposited $\mathrm{ZnO} / \mathrm{n}$-Si, annealing $\mathrm{ZnO} / \mathrm{n}$-Si and $(\mathrm{ITO} / \mathrm{ZnO}) / \mathrm{n}$-Si solar cells) 


\section{The Cleaning Sequences are:}

- The silicon wafers were washed ultrasonically in distilled water.

- They were washed in boiling acetone, then in boiled propanol for 5 minutes to remove greasy films.

- They were immersed in nitric acid $\mathrm{HNO}_{3}$ for $3 \mathrm{~min}$. in order to remove ionic contamination.

- The wafers were immersed in $\mathrm{HCl}: \mathrm{HNO}_{3}$ (3:1) for 3 min. to remove metallic films.

- They were etched in buffered hydrofluoric acid $\left(34.6 \% \mathrm{NH}_{4} \mathrm{~F}\right.$ : $6.8 \% \mathrm{HF}: 58.6 \% \mathrm{H}_{2} \mathrm{O}$ ) for $2 \mathrm{~min}$. to remove oxide films.

- The silicon wafers were cleaned in distilled water and dried in drier furnace at $120^{\circ} \mathrm{C}$.

\section{The Interfacial Layer Formation}

The insulator $\mathrm{SiO}_{2}$ layer on the front surface of silicon wafers was prepared by heating the silicon wafer at $450{ }^{\circ} \mathrm{C}$ in dry oxygen for different times (2-10 min.). Since there is no ellipsometer to measure the formed $\mathrm{SiO}_{2}$ film thickness accurately, the time of oxidation could be considered as a monitor of the film thickness.

\section{The Top Window Layer Deposition}

The $\mathrm{ZnO}$ thin films were deposited on microscope glass (MenzelGläser, Germany) slices by spray pyrolysis. The structural, optical and electrical characteristics were correlated with preparation parameters to optimize the best conditions fitting the solar cell performance. Some studies were carried out on the realized $\mathrm{ZnO}$ films published in previous papers [6]. Zinc oxide films are prepared from solution of $0.2 \mathrm{M}$ of pure hydrated zinc acetate $\mathrm{Zn}\left(\mathrm{CH}_{3} \mathrm{CO}_{2}\right)_{2} .2 \mathrm{H}_{2} \mathrm{O}$ dissolved in a mixed solution of $80 \%$ bi-distilled water and $20 \%$ methyl alcohol $\left(80 \% \mathrm{H}_{2} \mathrm{O}: 20 \% \mathrm{CH}_{3} \mathrm{OH}\right)$ at substrate temperature of $425{ }^{\circ} \mathrm{C}$ for 30 minute spray time, carrier gas of $20 \mathrm{~L} / \mathrm{min}$ and the solution flow rate of $3 \mathrm{~mL} / \mathrm{min}$.. A few drops of acetic acid are added to dissolve the reactant completely to avoid precipitation of Zinc hydroxide and maintain solubility of precursor. The management of substrate temperature and the solvent composition allow condensation of zinc oxide films in an almost one plane of growth with (002) preferred orientation as shown in Fig.(2). The high electrical resistivity of pure $\mathrm{ZnO}$ can be reduced by adding indium chloride $\mathrm{InCl}_{3}$ as a dopant to the precursor zinc acetate solution. The $\mathrm{ZnO}$ thin film incorporated with $2 \%$ In gives high conductivity $0.384 \times 10^{2}(\Omega . \mathrm{cm})^{-1}$. All the 
obtained films exhibit a high transmission $\sim 90 \%$ in the visible region with sharp absorption edge at $380 \mathrm{~nm}$ as shown in Fig. (3). The energy band gap of obtained $\mathrm{ZnO}$ films has a high value $3.26 \mathrm{eV}$ and hasn't change by indium addition and the refractive index is 1.9. These values enable the prepared $\mathrm{ZnO}$ acting as window and antireflection coating materials.

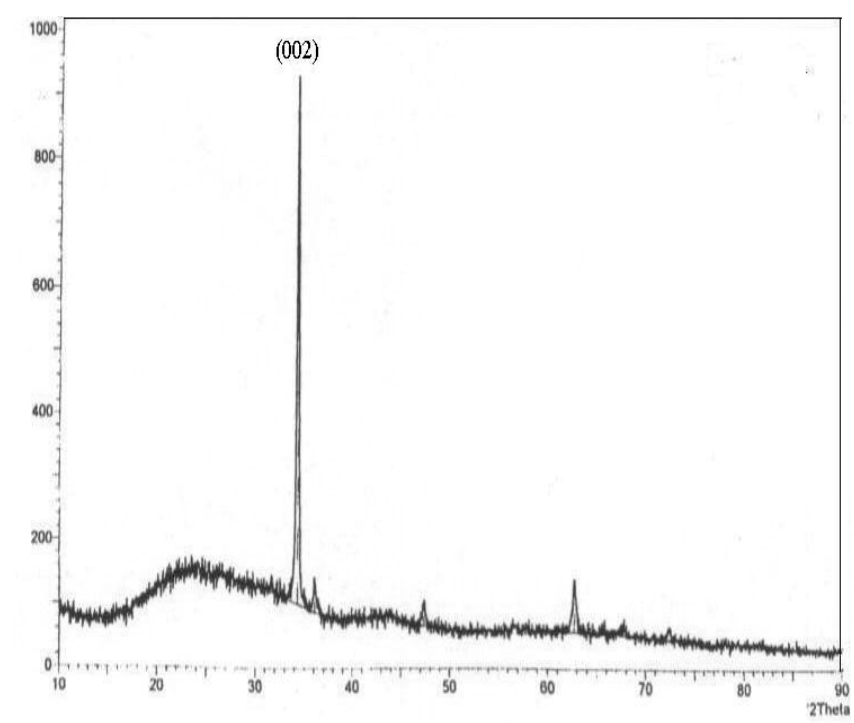

Fig. (2): XRD pattern for $\mathrm{ZnO}$ film prepared at $425^{\circ} \mathrm{C}$ for $30 \mathrm{~min}$ spray time and the solvent is $80 \% \mathrm{H}_{2} \mathrm{O}: 20 \% \mathrm{CH}_{3} \mathrm{OH}$.

\section{The Front and Back Contact}

Before the contact process, the backside of the devices was exposed to $10 \% \mathrm{HF}$ acid to remove the silicon dioxide $\mathrm{SiO}_{2}$ layer to decrease the series resistance. Indium has been found to form a good ohmic contact to the $\mathrm{ZnO}$, therefore $0.8 \mu \mathrm{m} \mathrm{In}$ is evaporated on the $\mathrm{ZnO}$ film through a metal shadow mask. The back contact was formed by evaporating about $1 \mu \mathrm{m} \mathrm{Ag}$ over the entire back side of the silicon. After the metallization process, the device is ready for evaluation and carrying out the required physical measurements. The edge portion of the silicon specimen was cut off to have electrical isolation between the rear and front surfaces. 


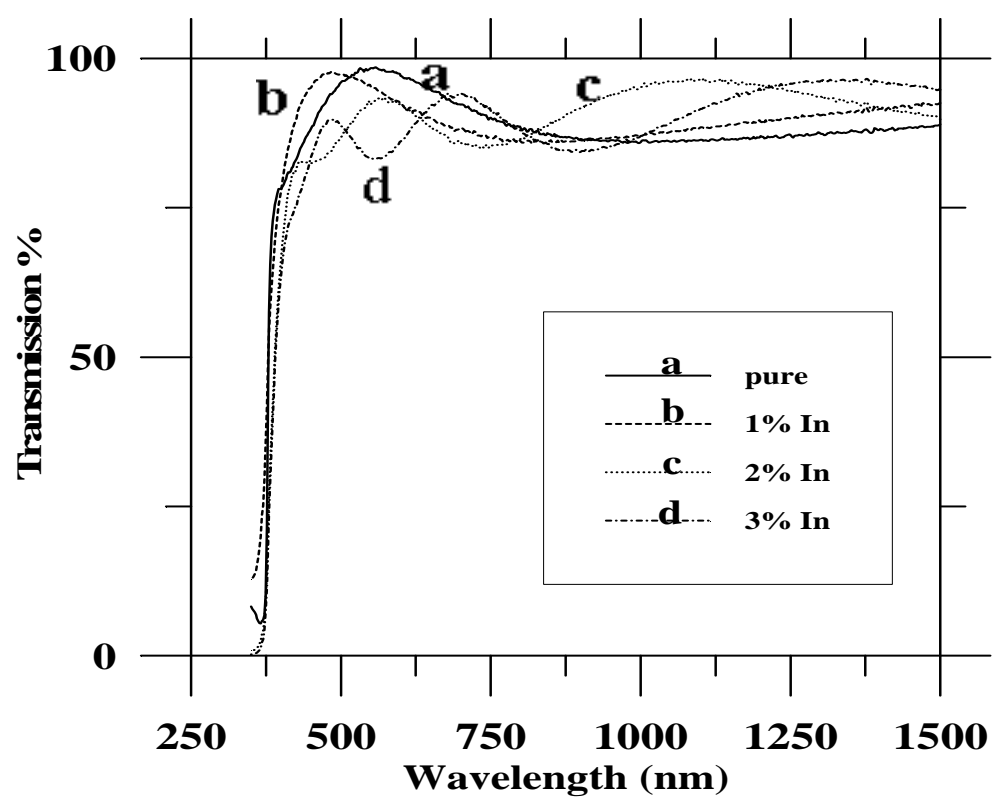

Fig. (3): The transmittance spectra of pure and doped $\mathrm{ZnO}$ thin films.

\section{Results and Discussions:}

\subsection{As-deposited $\mathrm{ZnO} / \mathrm{n}$-Si solar cells}

The illuminated I-V characteristics of as-deposited $\mathrm{ZnO} / \mathrm{n}-\mathrm{Si}$ solar cell prepared at $5 \mathrm{~min}$. oxidation time exhibits a poor photo response. The output parameters of $\mathrm{ZnO} / \mathrm{n}-\mathrm{Si}$ cell; open circuit voltage Voc, short circuit current density Jsc and fill factor FF are $232 \mathrm{mV}, 2.15 \mathrm{~mA} / \mathrm{cm}^{2}$ and 0.3 respectively. This poor performance was expected since the as-deposited $\mathrm{ZnO}$ films have relatively high sheet resistance. Such type of cell shows tendency to rapid degradation in performance after a short time ( $\sim 3$ days) although it is stored in dark. This behavior was attributed to the fact that, the relatively poor conducting $\mathrm{ZnO}$ films have the porous structure which allows oxygen to pass through it. The penetrated oxygen through $\mathrm{ZnO}$ layer increase thickness of the interfacial silicon dioxide layer for $\mathrm{ZnO} / \mathrm{n}-\mathrm{Si}$ cells. Therefore, the $\mathrm{SiO}_{2}$ interfacial layer with an optimum thickness is needed to control the barrier height between $\mathrm{ZnO}$ and $\mathrm{n}-\mathrm{Si}$. Table (1) indicates the cell output parameters measured immediately after fabrication and 3 days latter. 
Table (1): Photovoltaic parameters for as-deposited $\mathrm{ZnO} / \mathrm{n}-\mathrm{Si}$ solar cell measured immediately after fabrication and after 3 days.

\begin{tabular}{|c|c|c|c|c|}
\hline & $\mathbf{V}_{\mathbf{O C}}(\mathbf{m V})$ & $\mathbf{J}_{\mathbf{S C}}\left(\mathbf{m A} / \mathbf{c m}^{2}\right)$ & $\mathbf{F F}$ & $\eta(\boldsymbol{\%})$ \\
\hline Immediately & 232 & 2.15 & 0.33 & 0.18 \\
\hline After 3 days & 150 & 1 & 0.1 & - \\
\hline
\end{tabular}

\subsection{Annealed $\mathrm{ZnO} / \mathrm{SiO}_{2} / \mathrm{n}-\mathrm{Si}$ solar cells}

Generally, the electrical characteristics of $\mathrm{ZnO}$ could be enhanced by a proper doping with trivalent element and/or a suitable heat treatment in a reducing atmosphere (hydrogen) to change the stoichiometry of $\mathrm{ZnO}$ layer or inert atmosphere at certain temperature for a certain time to minimize the imperfections and increase the crystal size which allows an increase in the $\mathrm{J}_{\mathrm{SC}}$. As well the adsorbed oxygen on the zinc oxide surface and that diffused into the bulk are evolved leaving behind a donor state which increase the free carriers. Baik et al. [7] perform annealing at about $450{ }^{\circ} \mathrm{C}$ for 1 hour in hydrogen on $\mathrm{ZnO} / \mathrm{SiO}_{2} / \mathrm{n}-\mathrm{Si}$, also $\mathrm{H}$. Kobayashi et al. [8] annealed at $300{ }^{\circ} \mathrm{C}$ for 1 hour in vacuum and. Tomar et al. [9] perform annealing in nitrogen at $350{ }^{\circ} \mathrm{C}$ to improve the cell performance. In the present work, the heat treatment is carried out by annealing the cell at $350{ }^{\circ} \mathrm{C}$ in $\mathrm{N}_{2}$ for 40 minuets. It is observed that, heat treatment in nitrogen $\left(\mathrm{N}_{2}\right)$ results in large reduction of $\mathrm{ZnO}$ film sheet resistance because of oxygen desorption from the surface pores and grain boundaries, resulting in creation of vacant sites which will act as donor states The sheet resistance reduced from $2.11 \mathrm{~K} \Omega / \square(\Omega /$ Square $\mathrm{cm})$ for the adeposited film to a low value in the range $257 \Omega / \square(\Omega /$ Square $\mathrm{cm})$ as shown in Fig. (4). It is clear that the cell output parameters are improved and the stability was extended for long time as indicated in Table (2).

Table (2): Photovoltaic parameters for annealed $\mathrm{ZnO} / \mathrm{n}-\mathrm{Si}$ solar cell measured immediately after fabrication and after 30 days.

\begin{tabular}{|c|c|c|c|c|}
\hline & $\mathbf{V}_{\mathbf{O C}}(\mathbf{m V})$ & $\mathbf{J}_{\mathbf{S C}}\left(\mathbf{m A} \mathbf{A} \mathbf{c m}^{\mathbf{2}}\right)$ & $\mathbf{F F}$ & $\eta(\boldsymbol{\%})$ \\
\hline Immediately & 350 & 19 & 0.5 & 3.32 \\
\hline After 30 days & 300 & 16 & 0.4 & 1.92 \\
\hline
\end{tabular}




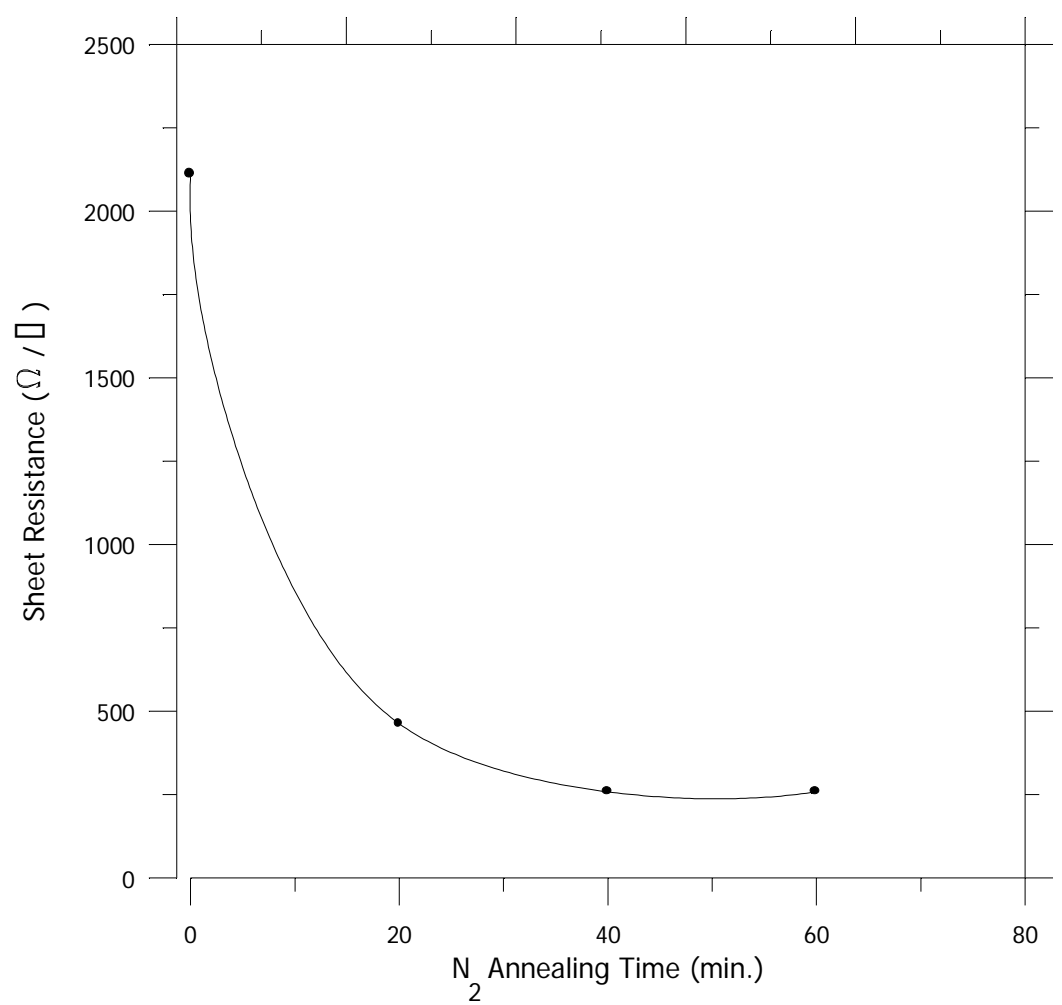

Fig. (4): The sheet resistance of $\mathrm{ZnO}$ : In annealed in $\mathrm{N}_{2}$ at $350^{\circ} \mathrm{C}$ for different time.

\subsection{ITO/ZnO/n-Si solar cells}

The degraded characteristic of $\mathrm{ZnO} / \mathrm{n}-\mathrm{Si}$ junction solar cells is minimized by depositing barrier layer for oxygen diffusion on the $\mathrm{ZnO} / \mathrm{n}-\mathrm{Si}$. A thin layer of ITO is deposited on $\mathrm{ZnO} / \mathrm{n}$-Si to suppress oxygen diffusion from the environment. ITO is highly transparent in the visible region $(\sim 90 \%)$ and has high electrical conductivity $\left(\sigma \sim 10^{4} \Omega^{-1} \mathrm{~cm}^{-1}\right)$. Solar cells covered with ITO are tested immediately and after 3 months from fabrication. Figure $(5: \mathrm{a}, \mathrm{b})$ shows the dark and illuminated I-V curves for ITO/ZnO-nSi solar cell under light intensity $100 \mathrm{~mW} / \mathrm{cm}^{2}$.It is observed that, the cell output parameters and the stability is further improved as indicated in Table (3). The observed stability of ITO/ZnO-nSi solar cell could be attributed to almost constant thickness (which could not be measured) of intentionally formed $\mathrm{SiO}_{2}$ layer. In contrast to $\mathrm{ZnO} / \mathrm{Si}$ solar cell, the oxygen diffuse through porous $\mathrm{ZnO}$ layer to $\mathrm{Si}$ substrate allowing more degradation of the cell performance due to the uncontrollable induced $\mathrm{SiO}_{2}$ layer. 
Table (3): Photovoltaic parameters for ITO/ZnO/n-Si solar cell measured immediately after fabrication and after three months.

\begin{tabular}{|c|c|c|c|c|}
\hline & $\mathbf{V}_{\mathbf{O C}}(\mathbf{m V})$ & $\mathbf{J}_{\mathbf{S C}}\left(\mathbf{m A} / \mathbf{c m}^{2}\right)$ & $\mathbf{F F}$ & $\eta \mathbf{\%}$ \\
\hline Immediately & 440 & 20 & 0.6 & 5.28 \\
\hline After 3 months & 435 & 19.8 & 0.57 & 5.1 \\
\hline
\end{tabular}

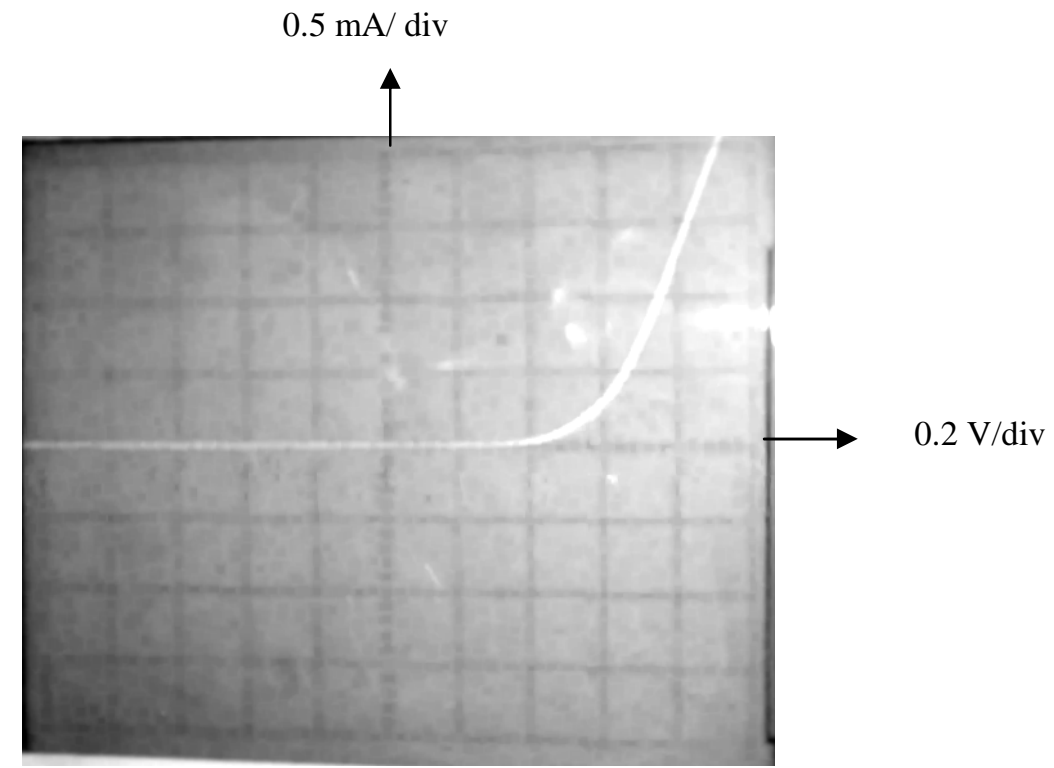

Fig. (5-a): Dark I-V characteristic of ITO/ZnO/n-Si solar cell prepared at 5 min oxidation time

\subsection{The effect of oxidation time}

The capacitance-voltage $(\mathrm{C}-\mathrm{V})$ characteristics are useful in obtaining information about the potential barrier at the junction, the semiconductor doping concentration and the presence of traps in materials. The plot of $1 / \mathrm{C}^{2}$ versus reverse bias for ITO/ $\mathrm{ZnO} / \mathrm{Si}$ solar cells at different oxidation time (2-10 min.) is shown in Fig. (6). The donor concentration $N_{D}$ and the built in potential $\mathrm{V}_{\mathrm{bi}}$ are estimated from the slope and the intercept of $1 / \mathrm{C}^{2}$ versus $\mathrm{V}_{\mathrm{a}}$ respectively. The barrier height $\varphi_{b}$ is related to built in potential $V_{b i}$ by the following formula [10]: 
$0.5 \mathrm{~mA} / \mathrm{div}$

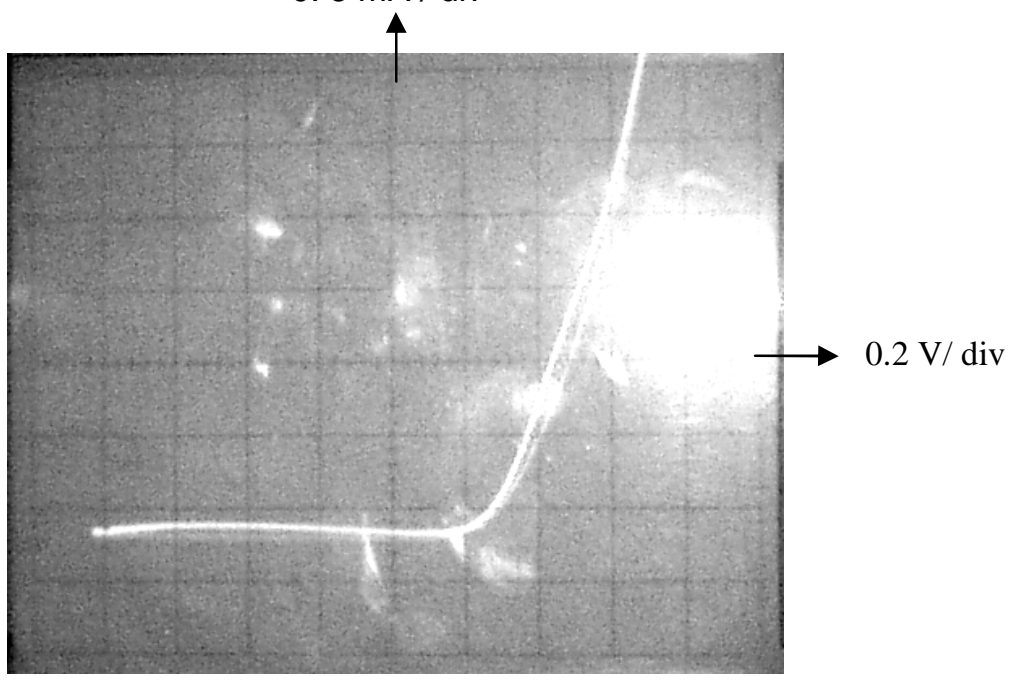

Fig. (5-b): Illuminated I-V characteristic of ITO/ZnO/n-Si solar cell prepared at 5 min oxidation time tested after 3 months of fabrications.

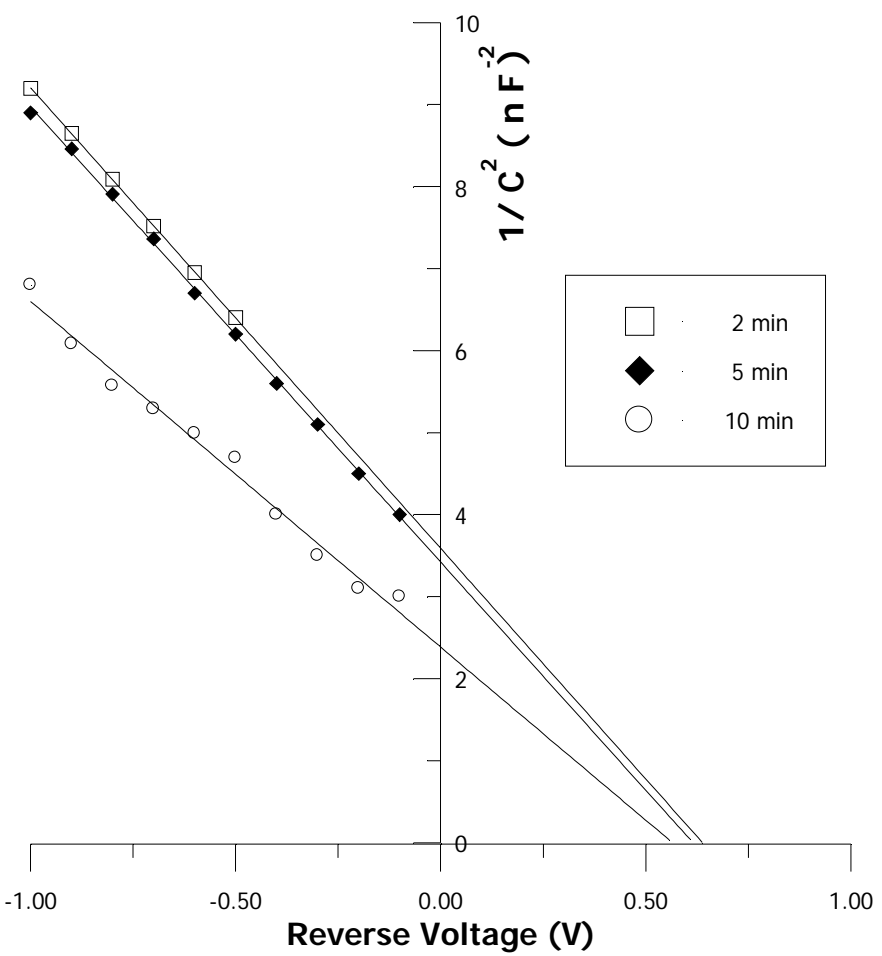

Fig. (6): The plot of $1 / \mathrm{C}^{2}$ versus reverse voltage for $\mathrm{ITO} / \mathrm{ZnO} / \mathrm{n}-\mathrm{Si}$ at different oxidation time. 


$$
\Phi_{\mathrm{b}}=\mathrm{qV}_{\mathrm{bi}}+\left(\mathrm{E}_{\mathrm{C}}-\mathrm{E}_{\mathrm{F}}\right)
$$

where $E_{C}-E_{F}$ is the difference between the conduction band energy and Fermi energy and depends upon the doping density and it is given by [11],

$$
E_{C}-E_{F}=\frac{K T}{q} \ln \left(\frac{N_{C}}{N_{D}}\right)
$$

where $\mathrm{N}_{\mathrm{C}}$ is the effective density of states in conduction band equal to $2.8 \times 10^{19} \mathrm{~cm}^{-3}$ for silicon [10], $\mathrm{K}$ is the Boltzmann constant equal to $1.381 \times 10^{-23}$ $\mathrm{J} / \mathrm{K}[10], \mathrm{T}$ is the temperature in Kelvin and $\mathrm{q}$ is the electronic charge equal to $1.6 \times 10^{-19} \mathrm{C}[10]$. The Si side doping concentration $\mathrm{N}_{\mathrm{D}}$ can be determined from the slop of straight line according to the following equation [10].

$$
\mathrm{N}_{\mathrm{D}}=\left(\frac{2}{\mathrm{q} \varepsilon_{\mathrm{s}} \varepsilon_{\mathrm{o}} \mathrm{A}^{2}}\right)\left(\frac{\Delta \mathrm{V}_{\mathrm{a}}}{\Delta \frac{1}{\mathrm{C}^{2}}}\right)
$$

where $\varepsilon_{\mathrm{s}}$ is the relative permittivity of silicon equal 11.9 [10], $\varepsilon_{\mathrm{o}}$ is the permittivity of free space equal $8.85 \times 10^{-12} \mathrm{~F} / \mathrm{m}[10]$ and $\mathrm{A}$ is the cell area equal $20 \mathrm{~mm}^{2}$.

The bulk Fermi level $\mathrm{E}_{\mathrm{F}}$ in the silicon is calculated to be $0.289 \mathrm{eV}$ from equation (1) after calculation the doping concentration using equation (3) below the conduction band edge $\mathrm{E}_{\mathrm{C}}$. The extrapolated built in potential $\mathrm{V}_{\mathrm{bi}}$ and the calculated donor concentration for $\mathrm{ZnO} / \mathrm{SiO}_{2} / \mathrm{Si}$ structure at 10 min oxidation time is $0.57 \mathrm{~V}$ and $4.16 \times 10^{14} \mathrm{~cm}^{-3}$ respectively. The calculated values of $\mathrm{N}_{\mathrm{D}}$ are consistent with the known resistivity of the used silicon as depicted from the following equation [11]

$$
\rho=\frac{1}{q \mu_{n} N_{D}}
$$

where $\mu_{\mathrm{n}}$ is the mobility of electron in silicon and equal $1350 \mathrm{~cm}^{2} / \mathrm{V} . \mathrm{S}$ [10]. The above equation gives a resistivity $11 \Omega$.cm while the used resistivity is in the range 10-20 $\Omega . \mathrm{cm}$. It is observed that the decrease of photovoltage is caused by lowering the energy barrier height. The variation of open circuit voltage $V_{o c}$ 
and barrier height $\varphi_{\mathrm{b}}$ as a function of oxidation time are shown in Fig. (7). The obtained results was supported by Ashok et al. [12], who reported the changes in built-in voltage in the range 0.80 to $0.65 \mathrm{~V}$ with increasing the oxidation time ( 0 - 15 min.), while the obtained results changes in the range 0.0 .67 to $0.57 \mathrm{~V}$. with increasing the oxidation time (2-10 $\mathrm{min}$.).

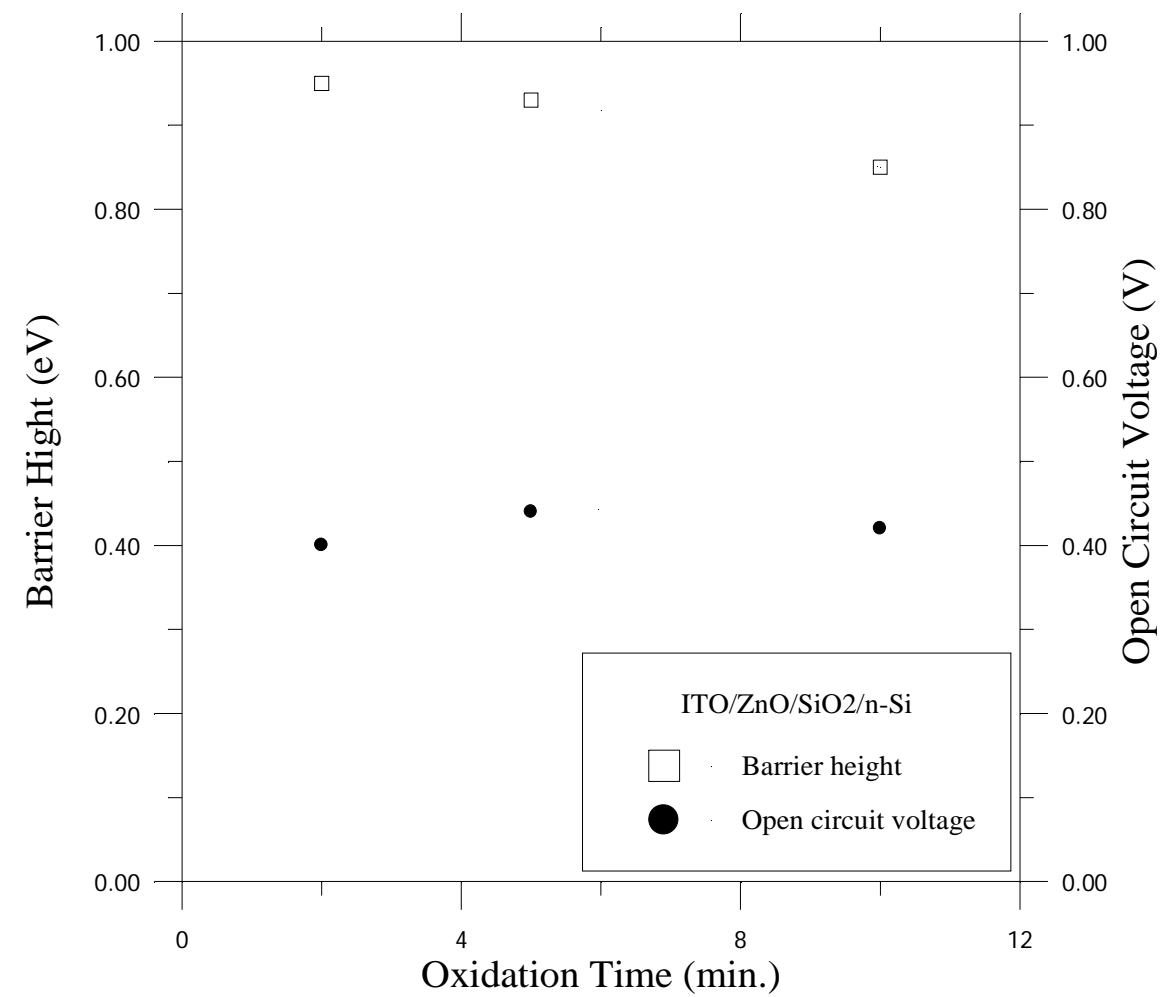

Fig. (7): The variation of the barrier height $\left(\varphi_{\mathrm{b}}\right)$ and open circuit voltage $\left(\mathrm{V}_{\mathrm{oc}}\right)$ as a function of oxidation time.

\section{Conclusions:}

Zinc oxide/ monocrystalline silicon solar cell is realized by spraying 0.2 $\mathrm{M}$ zinc acetate dissolved in a solvent composed of $80 \% \mathrm{H}_{2} \mathrm{O}: 20 \% \mathrm{CH}_{3} \mathrm{OH}$. The $\mathrm{ZnO} / \mathrm{Si}$ solar cell with an interfacial $\mathrm{SiO}_{2}$ layer formed by oxidation shows a considerable degradation of its performance. To minimize cell degradation a layer of ITO is deposited on the ZnO surface. The ITO layer almost prevent diffusion of atmospheric oxygen to $\mathrm{Si}$ wafer which allowing the increase of the intentionally formed $\mathrm{SiO}_{2}$ interfacial layer. 


\section{References:}

1. E. M. Bachari, G. Baud, S. Ben Amor, M. Jacquet, Thin Solid Films, 348, 165 (1999).

2. Jin Ma, Feng Ji, Hong-Lei Ma, Shu-Ying Li, Solar Energy Materials \& Solar Cells 60, 341 (2000).

3. Y. Natsume, H. Sakata, Journal of Material Science: Materials in Electrons 12, 87 (2001).

4. W. Tang and D. C. Cameron, Thin Solid Films, 238, 83 (1994).

5. A. Tiburcio-Silver, A. Sanchez-Juarez, A. Avila-Garcia, Solar Energy Materials \& Solar Cells, 55, 3 (1998).

6. H. H. Afify, S. H. El-Hefnawi, A. Elwia, M. Abd-El Naby and N. M. Ahamed $3^{\text {rd }}$ World Conference photovoltaic Energy Conversion, Osaka, 165, Japan 11-18 May, (2003).

7. D.G. Baik, S. M. Cho Thin Solid Films, 354, 227 (1999).

8. H. Kobayashi, H. Mori, T. Ishida, and Y. Nakato, J. Appl. Phys., 77, 1301 (1995).

9. M.S. Tomar and F. J. Garcia, Solar and Wind Energy, 1, 71 (1984).

10. M. S. Tyagi "Introduction to Semiconductor Materials and Devices" John Wiley\&Sons, Inc (1991).

11. Martin A. Green "Solar Cells; Operating, Principles, Technology and System Applications", university of New South Wales, (1992).

12. S. Ashok, Panduranga P. Sharma and Stephen J. Fonash, IEEE Transactions on Electron Devices,. ED,. 27, 425 (1980). 